\title{
Feridun Oral's children's books' peritextual features and their text readability levels
}

\author{
Bilge Gök ${ }^{(D)}$ \\ Hacettepe University, Faculty of Education, Ankara, Turkey, bilgeb@ hacettepe.edu.tr \\ Fahri Temizyürek ${ }^{(D)}$ \\ Gazi University, Faculty of Education, Ankara, Turkey, fahri@gazi.edu.tr \\ Özlem Baş ${ }^{\text {D }}$ \\ Hacettepe University, Faculty of Education, Ankara, Turkey, ozlembas@hacettepe.edu.tr \\ Özgür Sirem ${ }^{(D)}$
}

Ministry of National Education, Board of Education and Discipline, Ankara, Turkey, dr.ozgursirem@gmail.com

\begin{abstract}
In this study, it was aimed to determine the level of the peritextual features of Feridun Oral's children's books, the readability of the texts, what the subject and main ideas are. The research was designed according to the holistic multi-case pattern of the qualitative methods. 13 storybooks from the works of Feridun Oral were used as data sources. Document analysis method was used to collect data in the study. Both descriptive analysis and thematic content analysis were used in the analysis of the data obtained in the study. As a result of the analysis, although it was seen that all of the books, which are data sources, got close and high scores in terms of peritextual features, it was revealed that the author reflected certain practices in all his books in terms of design features. When the average level of readability of all the books considered within the scope of the research was examined, it was seen that the books are generally easy. When the data sources were examined in terms of the codes they contain, it included instilling the values of "responsibility, determination, respect, inclusiveness, solidarity, social aid, love of animals, protection of nature and living things" to the reader.
\end{abstract}

\section{Feridun Oral'ın çocuk kitaplarının peritextual özellikleri ile metinlerinin okunabilirlik düzeyleri}

ÖZ Bu araştırmada Feridun Oral'ın çocuk kitaplarının peritextual özellikleri, metinlerin okunabilirlik düzeyi, işledikleri konu ve ana fikirlerin neler olduğunun belirlenmesi amaçlanmıştır. Araştırma nitel yaklaşımla bütüncül çoklu durum desenine uygun olarak tasarlanmıştır. Veri kaynağı olarak Feridun Oral'ın özellikle tek başına yazıp çizdiği eserlerinden 13 hikâye kitabı kullanılmışır. Çalışmada veri toplama yöntemi olarak doküman incelemesi kullanılmıştır. Araştırmada verilerin analizinde betimsel analiz ve tematik içerik analizi yöntemleri kullanılmıştır. Araştırmanın sonucunda veri kaynakları olan kitapların tamamının peritextual özellikleri açısından birbirine yakın ve yüksek puanlar aldığı görülmekle beraber tasarım özellikleri bakımından yazarın belirli uygulamaları tüm kitaplarına yansıttığı ortaya konmuştur. Araştırma kapsamında ele alınan tüm kitapların okunabilirlik düzeyinin ortalaması incelendiğinde kitapların genel olarak kolay olduğu görülmektedir. Veri kaynakları içerdikleri kodlar açısından incelendiğinde "sorumluluk, azim, saygı, kapsayıcılık, dayanışma, yardımlaşma, hayvan sevgisi, doğayı ve canlıları koruma" değerlerini okuyucuya aşılamayı içermektedir.

Anahtar 


\section{INTRODUCTION}

The contributions of children's books- which occupy an important place in children's lives and which shape their future- to children's development are associated with the quality and functionality of the books. Arousing curiosity and attracting interest (Y1ld1z et al., 2016), suitability to children's level of development in terms of content, illustrations and physical properties are only a few of the most important features of good quality and functional children's books (Toran \& Dilek, 2017). While children's books which are successful and that are written in the right way inculcate reading habits and love of reading in children, the ones which are not prepared in consistency with pedagogical principles move children away from reading habit. Therefore, special care should be taken with books prepared for children and special attention should be paid to them. Children's books should contain properties that introduce individuals to life from a realistic perspective. Lüle (2007) points out that books for children should prepare individuals to life, present the intended messages and events in children's developmental process, that they should not use pressurizing language and that they should bridge the gap in children's knowledge. Any work of literature in the area certainly has a message to give (Yalçın \& Aytaş, 2003). Thus, children's books support the education offered by teachers, families, and schools. How important books- which create children's vision of the future- should not be forgotten.

Three main factors are influential in making children read a book voluntarily and with pleasure: the written text of the book, all other unwritten elements, and the topic and main idea of the book. The first of the three is all the elements that attract children's interest in seeing the book for the first timeapart from the written text. They are called peritextual features. Children make peritextual reading in this way. The word peritext needs explaining to understand the concept of peritextual because there may not be a corresponding word in some languages. The parts of a book such as the front and the back of the book cover, dust jacket, bind, blank pages after the front cover and before the back cover, the title page, bookplate, pages on which the publisher, illustrator, editors are written and dedication pages such as acknowledgements page are known as peritext (Genette, 1997). These elements- which surround a story- need to be planned with care and attention to prepare readers for the story (Sipe, 2010) because peritextual features enable readers to decide on whether to read a story or not. Those features can be very useful in comprehending a story as a whole and in interpreting it (Sipe \& Pantaleo, 2008). According to Higonnet (1990), peritextual features are planned to provide an aesthetic introduction to a story and to build integrity between the elements of the story. Thus, peritextual features should be handled duly in the process of reading a book with children and in introducing the book to them (Sipe, 2010). Examining the peritextual features of pictorial children's books enable readers to make predictions about the story in the book, to activate their prior knowledge, and to make inferences about the text (Moss, 2005). Such features also facilitate students' preparation for reading and develop their meaning-making skills. When seen from this perspective, organizing peritextual features in a book according to the principle of relativism helps children to discover a text in-depth, to gain experience related to the text, and enables offering more opportunities to interpret the text (Serafini, 2012).

Children begin to read the text after exploring the peritextual features of a book. There are two dimensions of reading a text: legibility and readability. Indeed, in what font and in what type size a text is written for children- that is to say, the legibility of a text- can be considered as the peritextual features of the text. It is because children examine such features before reading a text, and thus they decide to read or not to read it. The concept of readability is the extent to which a text is easy or difficult for a reader to comprehend (Ateşman, 1997). According to Gögüş (1978), however, readability is the ability of a student at a certain level to read and comprehend a piece of writing. Temur (2003) thinks that there are formulas in readability, and the readability formulas are used in assessing written homework, in choosing appropriate texts for coursebooks, and in choosing appropriate books for an individual or a group. It can be said that readability should be determined to 
identify the level of books to be recommended to students, to decide on what level of books can be read, and to offer guidance. The books, which are appropriate in terms of readability, are easier for students to read and to comprehend (Klare, 1988).

The attractiveness of peritextual features in children's books, easiness in terms of readability, and children's concluding after reading the books are the three important parts of reading. Başaran (2019, p.301) stresses that one of the main indicators of whether or not a student has comprehended a text correctly is to find the main idea of the text, and the researcher also argues that the topic of a text and the author's purpose should be identified to be able to find the main idea of the text. Therefore, narrative children's books need to have a clear and understandable main idea. Readers try to interpret with their prior knowledge and experiences as a part of their relations with a text.

The texts (story, fairy tale, etc.) in children's books appear in different ways. Therefore, it can be said that these texts should have some features specific to the text. Having features such as; the visuals in the text can be presented in different formats; Concretizing the intangible assets by giving examples; easy comprehension of the text by the reader; developing critical thinking and evaluating skills in a children's book will increase the permanence in reading. In this sense, it can be said that examining text features, especially in children's books, will provide more benefits to readers.

Considering all these features that explain the relationship of the reader with the text, it becomes clear that children's books should be selected in the context of "Reader Response Theory". In the selected children's picture books, both the peritextual features and the readability features of the texts affect the meaning that children will attribute to the book in terms of structure and design. When the content, the subject in the book, and the main idea are included in these elements, it is thought that the "Reader Response Theory" will raise awareness of the educators to understand the child's world in the selection of qualified sources.

Reader Response Theory, which considers the relations between readers and texts, calls attention to the aesthetic and meaning-making aspects of reading in building meaning. In this context, books affect children's knowledge as well as their feelings and thoughts. (March, 2019, pp.84-85). Readers' individual and cultural differences cause readers to infer different meanings from the text they read within the scope of the theory- which attracts attention to both the knowledge dimension and the aesthetic elements of reading. In this way, readers build new meanings (Chase \& Cynthia, 1987, p.531). Out-of-the text elements (peritextual features), as well as the textual features of a book (readability and main idea), are the points with which care should be taken in building the meaning. Several studies concerning the selection of children's books and the importance of readability, peritextual features, topic, and main idea in selecting books are available in the literature (Ateşman, 1997, Genette, 1997; Higonnet, 1990; Toran \& Dilek, 2017; Ural, 2006; Veziroğlu \& Gönen 2012; Y1ldiz et al., 2016). Yet, no studies considering texts in terms of their peritextual features and the readability and evaluating books in terms of their topics and main ideas as a whole were not found in the literature in Turkey. Thus, the study is expected to guide researchers who would like to work in the area. It offers a wide range of examples by considering the readability levels of the books chosen for children's reading by setting out from books written by Feridun Oral- who has produced works of art in children's literature which have national and international significance- by offering educators and researchers a ready-made form to analyze the peritextual features of texts and by describing in a qualitative conception what books instill in children through their topics and main ideas. Therefore, it is thought to raise educators', teachers', and parents' awareness of looking at books scientifically by using plain language.

This paper aims to identify the levels of children's books written by Feridun Oral in terms of peritextual features and readability and to find the topics covered in the books selected and the main ideas in them. In the light of this general purpose, it also has the following sub-purposes about Feridun Oral books: 
- What are the peritextual features?

- At what level are they in terms of readability?

- What topic and main ideas do they have?

\section{METHODOLOGY}

\section{Research Design}

This study employs a qualitative research design- which makes efforts to obtain in depth information by questioning the "why" rather than the "how much" of the subject of research in which the relations, activities, situations, and materials are examined (Fraenkel et al., 2012). The research was conducted by holistic multiple case study. The case study is a research method that puts the questions of "how" and "why" in the center and which enables researchers to analyze in-depth the phenomena and events which they cannot control (Gay et al., 2011). More than one case, which can be perceived holistically on their own are available in holistic multiple case study (Yıldırım \& Şimşek, 2018, p.301). This paper aims to analyze the works of children's literature written and illustrated by Feridun Oral and to demonstrate the written and unwritten content of the books as it is.

\section{Sources of Data}

13 storybooks by Feridun Oral- It was selected according to the method of convenience samplingwere used in this study as the material, and the needed research ethics committee approval was received from the publisher. The reason for choosing Feridun Oral as the author was that he was one of the illustrators of children's books in the area of children's literature in Turkey. Besides, several books of the author were given the best pictorial children's books/ storybooks of the year award nationally and internationally. Thus, the author's international recognition and a great number of awards were also among the criteria for preferring the author for analysis. Another criterion is also these books present basic life problems to children. The author is also the co-author and co-illustrator of several books. For all these reasons, the criterion-sampling method was used in selecting the sources of data, and only the books written and illustrated by the author were included in the sample. The sample was fundamentally based on studying a series of cases, which meet the criterion (Yıldirım \& Şimşek, 2018, p.122).

The books analyzed within the scope of this study included the following: "Bögürtlen Cini ve Sar1 Gaga" (Blackberry Genie and the Yellow Beak), "Pirinç Lapaso ve Küçük Ejderha" (Rice Porridge and Little Dragon), "Meyveleri Kim Yemiş?" (Who ate the fruit?), "Kirpi ile Kestane" (Th Hedgehog and Chestnut), "Kırmızı Kanatlı Baykuş" (The Owl with Read Wings), "Kırmızı Elma" (The Red Apple), "Guguklu Saatin Küçük Kuşu" (The Little Bird of the Cuckoo Clock), "Farklı ama Aynı" (Different but the Same), "Ay Ne Zaman Gelecek?" (When will the Moon Come?), "Babaannem Kime Benziyor?" (who does My Grandma Look Like?), "Baloncu Dede ve Üç Küçük Yaramaz?" (The old man Who sells Ballons and Three Little Naught Children), "Benekli Faremi Gördünüz mü?" (Have Seen my Speckled Mouse?) and "Yağmurlu Bir Gün" (A Rainy Day).

\section{Validity and Reliability}

Researchers were diversified in data analysis in this study to secure persuasiveness. Thus, three researchers analyzed the sources of data. (One of these researchers is an associate professor in the field of assessment and evaluation, the other researcher is an associate professor in the field of Turkish and basal reading and writing, and another researcher has a Doctorate in teaching Turkish.) Afterward, an academician who had expertise in children literature - also a professor of this topic- examined the analysis of the data and the strategy of the expert examination was used in this way. 
All of the findings were presented without making any comments on them to make the research consistent. In addition to that, the books analyzed were marked by two different experts/researchers according to the "peritextual features evaluation form" prepared by the researchers (an associate professor in the field of children's literature and also a doctor lecturer in the field of children's literature), and "Kappa Coefficient" was taken into consideration in calculating the agreement between the raters. Accordingly, the interrater agreement was found as 0.83 following the Cohen Kappa analysis. Based on the result, the interrater agreement can be said to be perfect (Landish \& Koch, 1977) and the coding can be said to be consistent/reliable.

Purposeful sampling was considered essential to secure transferability in the study, and the data were preserved as they were for use by other researchers for verifiability. Additionally, efforts were made to offer a detailed description of the process and what is done in the process to increase transferability. In this context, each stage of the research was described in detail, and the results obtained were presented in comparison with the results obtained in other studies.

\section{Data Collection and Analysis}

The method of document analysis (descriptive and thematic content analyses) was used in analyzing the data collected in this study. Document analysis involves analyzing the written material, which contains information on the phenomena and events intended to be researched. Document analysis can be used in combination with other methods as well as functioning as a method of data collection on its own (Yıldırım \& Şimşek, 2018, p.189). It was used as a data collection method on its own in this study. For this purpose, first, the selected 13 books were read one by one, and the number of syllables, words, and sentences in the books was found. Then, the formula below-which was developed by Flesch (1948) and which was adapted into Turkish by Ateşman (1997) by considering the average length of words and sentences in Turkish- was used to find the readability of the books:

The number of readability $=(198.825-40.175 X 1)-(2.610 X 2)$

$\mathrm{X} 1=$ The average length of words in syllables

$\mathrm{X} 2=$ The average length of sentences in words (Ateşman, 1997, p. 74)

The number of syllables, words, and sentences was first found in each book to be able to apply the formula. The number of syllables was divided into the number of words to find the average length of words. After that, the readability level of the books was found by using Ateşman's (1997) abovementioned formula. Accordingly, the readability levels for the number of readabilities were as in the following: 90-100: very easy, 70-89: easy, 50-69: medium, 30-49 difficult, 1-29: very difficult (p.74).

Both descriptive and thematic content analyses were used in analyzing the research data. The peritextual features of the sources of data in this study were analyzed within the framework set through descriptive analysis. The "Peritextual Features Evaluation Form" prepared by the researchers was used for the analyses. The form contained 10 items. The "yes" answers were marked as 2 points whereas the "partially yes" answers were marked as 1 point and the "No" answers were marked as 0 points in the form. In this case, the maximum score receivable from the evaluation form was 20 . The final draft of the "Peritextual Features Evaluation Form"- which was shaped by the views obtained- is shown in Table 1.

Coding was done in a general framework while doing the content analysis. A general conceptual structure is formed before analyzing the data in such coding (Yıldırım \& Şimşek, 2018, p.246). The structure was formed by revealing the subjects and the main ideas in the books and thus, the codes in each book category were distinguished. From the codes, a common theme was reached. 


\section{FINDINGS AND INTERPRETATION}

This study aimed to analyze children's books written by Feridun Oral in terms of their peritextual features, readability levels, subjects, and main ideas in the texts. The findings for the peritextual features of the selected books for the first sub-problem of the study are shown in Table 1.

Table 1.

The Total Scores for the Sources of Data in the Peritextual Features Evaluation Form

\begin{tabular}{lc}
\hline Book Title & Peritextual features evaluation form total scores \\
\hline The Old Man Who Sells Balloons and Three Little Naughty Children & 20 \\
Have you Seen My Speckled Mouse? & 19 \\
Who does My Grandma Look Like? & 19 \\
Different but the Same & 19 \\
The Owl with Red Wings & 18 \\
Rice Porridge and the Little Dragon & 18 \\
A Rainy Day & 18 \\
The Little Bird of the Cuckoo Clock & 17 \\
When will the Moon Come? & 17 \\
The Red Apple & 16 \\
The Blackberry Genie and the Yellow Beak & 16 \\
Who ate the Fruit? & 15 \\
The Hedgehog and the Chestnut & 15 \\
\hline
\end{tabular}

Accordingly, the book with the highest score in terms of pretextual features is The Old Man Who Sells Balloons and Three Little Children whereas the one with the lowest score is The Hedgehog and the Chestnut. The books- the sources of data- were similar in terms of peritextual features and they had high scores; besides, it was also found that the author had reflected certain practices into all the books in terms of design. The books were made of thick and burble materials in the technique of lamination binding. The front cover as well as the back cover of all the books had pictures associating the stories in the books. All the books included the name and surname of the author on the external cover. The books entitled "The old man Who sells Balloons and Three Little Children", "Have you Seen my Speckled Mouse?", "Who does My Grandma Look Like?" and "Different but the Same" received the whole point in marking in the item "does the main character communicate with readers through the cover?"- which caused a difference in marking. It became on looking at the book covers that the main characters communicated with readers and that the communication was about the content.

Whether or not the font, which was chosen as different in the number of syllables, words, and sentences, was legible in terms of visual properties and whether not it was written in suitable type size was analyzed. Within the scope of the item, the books entitled "The old man Who sells Balloons and Three Little Children", "Who does My Grandma Look Like?", "A Rainy Day", "Rice Porridge and the Little Dragon" received the whole point. The author's biography and his works were included on the front and back internal covers of all the books. The visuals drawn by the author were marked in whole points because they represented the colors and characters and because they were connected with the subject.

Research question two examined the readability levels of the books- which were included in the sources of data collection. The length of words and sentences and the number of readabilities in each book are shown in Table 2.

According to Table 2, the length of words is between 2.40 and 2.78 and the length of sentences is between 5.37 and 15.65 while the readability number is between 48.41 and 86.32 in Feridun Oral's children books- which are analyzed in this study. According to readability classification made by Ateşman (1997), it can be said that "The Old Man Who Sells Balloons and Three Naughty Children" is "difficult, "The Read Apple" and "Have You Seen My Speckled Mouse" are "medium" and "The Blackberry Genie and the Yellow Beak", "Rice Porridge and the Little Dragon", "Who ate the Fruit?", "The Hedgehog and the Chestnut", "The Owl with Red Wings", "The Little Bird of the Cuckoo Clock", "Different but the Same", "When will the Moon Come?", "Who does My Grandma Look 
Like?" and "A Rainy Day" are easy to read. Accordingly, all except for three of the books can be said to be easy in terms of readability level. An examination of the average for all the books also shows that the books, in general, are easy. Apart from that, the book with the smallest readability number and thus the most difficult book- was "The Old Man Who Sells Balloons and Three Naughty Children" while the book with the greatest readability number- and thus the easiest book-was "The Hedgehog and the Chestnut". There were no books, which were considered as "very difficult", or "very easy"- as clear from Figure 1.

Table 2.

The Length of Words and Sentences and the Number of Readabilities in the Books Analyzed

\begin{tabular}{lllll}
\hline Rank & Title & $\begin{array}{l}\text { Length of } \\
\text { words }\end{array}$ & $\begin{array}{l}\text { Length of } \\
\text { sentences }\end{array}$ & $\begin{array}{l}\text { Readability } \\
\text { number }\end{array}$ \\
\hline 1 & The Hedgehog and the Chestnut & 2.40 & 6.15 & 86.32 \\
2 & When will the Moon Come? & 2.43 & 6.29 & 84.60 \\
3 & Who ate the Fruit? & 2.41 & 7.67 & 81.86 \\
4 & The Owl with Red Wings & 2.63 & 6.06 & 77.53 \\
5 & The Blackberry Genie and the Yellow Beak & 2.51 & 9.27 & 73.64 \\
6 & A Rainy Day & 2.78 & 5.37 & 73.07 \\
7 & The Little Bird of the Cuckoo Clock & 2.58 & 8.72 & 72.56 \\
8 & Who does My Grandma Look Like? & 2.58 & 8.61 & 72.56 \\
9 & Different but the Same & 2.72 & 7.02 & 70.67 \\
10 & Rice Porridge and the Little Dragon & 2.56 & 9.63 & 65.32 \\
11 & The Red Apple & 2.67 & 10.09 & 63.53 \\
12 & Have you Seen My Speckled Mouse? & 2.67 & 10.70 & 48.41 \\
13 & The Old Man Who Sells Balloons and Three & 2.72 & 15.65 & 72.41 \\
& Little Naughty Children & & & \\
\hline
\end{tabular}

Figure 1.

The Chart for the Distribution of Readability

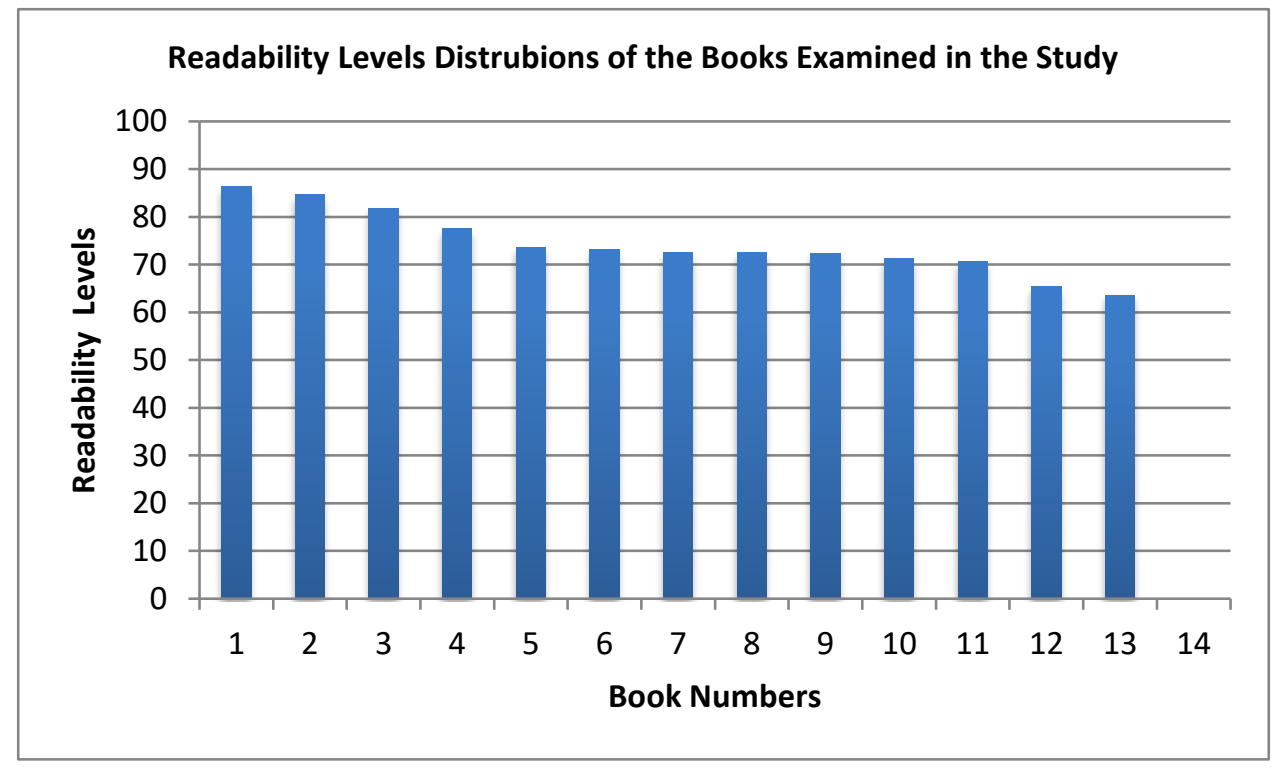

The theme, which emerged from research question three, was the teaching of various values using main ideas in the books. Each book was considered in the theme of values and thus analyzed, and the concepts, which were reached based on subjects and main ideas, were coded. The themes, categories, and codes in the books are shown in Appendix 1. 
Accordingly, all the sources of data (all of the books) intend to instill in students such values as responsibility, determination, inclusiveness, solidarity, helping each other, love for animals, and protecting nature and living creatures. These conceptual codes are included in the theme of values.

\section{DISCUSSION, CONCLUSION AND RECOMMENDATIONS}

This paper-which aimed to analyze the children's books written by Feridun Oral in terms of the peritextual features of the books and the readability of the texts- sought answers to the question of what the peritextual features of Feridun Oral books are for primary school students in the first subproblem of the research. As a result, it was found that the book with the highest score in terms of peritextual features was "The Old Man Who sells Balloons and "Three Little Naughty Children" whereas the book with the lowest score was "The Hedgehog and the Chestnut". It was demonstrated in this study that all of the books- which were the sources of data- were similar in terms of peritextual features with high scores in this respect and that the author had reflected certain properties of design into all the books. Considering the claim made by Moss (2005) that peritextual features in pictorial children's books enable children to make predictions before reading, to activate their prior knowledge, and to make inferences about a text; it can be said that the Feridun Oral books examined in this paper will be useful for primary school students in a similar way, Gönen (2017), in another study conducted about Feridun Oral's storybooks, also concluded that peritextual features were high physically and formally. Demir (2019) also concluded in parallel to the conclusion of this current study that the illustrations of Feridun Oral books were qualified by $91 \%$ in form, by $80 \%$ in content, and by $99 \%$ in art. It became apparent that illustration, one of the properties of peritextual reading, was used effectively in Feridun Oral books. This study draws attention to all of the peritextual features with the descriptive data revealed by primary school teachers on how to examine quality children's books in terms of visual elements. Thus, it exemplifies the handling of not only visuals but also all non-textual elements in a child-friendly manner.

This paper sought answers to the question of what the level of Feridun Oral books in readability for primary school students in the scope of the second sub-problem is. An examination of the average for all the books considered in this paper showed that they were easy in general. Baş and Inan Yıldiz (2015, p.52) analyzed the texts in the Turkish coursebook for second graders in terms of readability and found that the narrative texts had higher readability scores than the informative texts. The finding is supportive of the fact that all the Feridun Oral books analyzed are narrative and that they generally are easy to read. In addition to that, it was also found in this study that the book with the lowest readability number- and therefore the most difficult book to read- was "The Old Man Who Sells Balloons and Three Little Naughty Children" but the book with the highest readability score- and therefore the easiest book to read- was "The Hedgehog and the Chestnut". Having short and simple words and sentences increases the readability of books in children's literature (Güneş, 2000; Temizyürek, 2010, p.652). The book entitled "The Old Man Who Sells Balloons and Three Little Naughty Children" had a word length of 2.72 (2.59 on average), sentence length of 6.15 (8.56 on average), and readability coefficient of 86.32 (72.41 on average). The findings in this study indicated that the book "The Old Man Who Sells Balloons and Three Little Naughty Children" was not short or simple but that the book entitled "The Hedgehog and the Chestnut" was short and simple. This situation showed that "The Old Man Who Sells Balloons and Three Little Naughty Children" differed in the scores it received from peritextual features and readability level. Thus, the difficulty in the readability criterion for the book can be overcome with support through peritextual reading. This is a situation, which demonstrates the contributions peritextual features can make to reading texts.

The attractive visual features of children's books can be effective in primary school children to show interest in these books. However, when looking at the text feature, which is a critical element in terms of reading comprehension, it has been revealed that conducting readability examinations is of great importance. Considering the memory development of primary school children, the number of syllables 
in the texts they read is an important factor in the simultaneous execution of reading and comprehension. For this reason, the suitability of the texts to child development and level should be determined by using readability formulas based on the number of syllables.

In the third research problem, answers were sought to the question of what topics and main ideas Feridun Oral's children's books presented. An examination of the books in terms of codes made it clear that the values of responsibility, determination, respect, inclusiveness, solidarity, helping, love for animals, protecting nature and living creatures were instilled in readers. The conceptual codes mentioned were included in the theme of values. In a paper entitled "An Analysis of the Values in Feridun Oral's Pictorial Story Books", Dilek (2017) conducted a case study using the values set by the Ministry of National Education (MoNE). The researcher concluded that such diverse values as love, responsibility, tolerance, friendship, politeness, and cooperation-solidarity were considered. It was a result in parallel to the ones obtained in this study. In this research, the codes that emerge in line with the content analysis constitute the values. For this reason, value classification analysis was not used. As a result of the examination of the subject and main ideas to find an answer to the research problem, it was determined that some values were processed in the contents of the books.

Based on the results obtained in this study, future researchers can be recommended to analyze different writers' books in children's literature in terms of the features considered in this paper or other features. The deficiencies found in the books analyzed can thus be eliminated by writers and publishers. The children's books published in Turkey and abroad and the children's books written in Turkish or translated into Turkish from another language can also be analyzed in this context. The results to be obtained will contribute to the development of children's literature. As the number of books analyzed in such studies increases, books can be recommended to teachers according to grade levels. Additionally, teachers can be made to recommend their students' books according to their levels of reading based on readability levels found in this study. Several activities are done in primary schools as values education; but the teachers who want to instill those values in their students can be recommended to use the books analyzed in this study considering the values, which emerged in this paper. Values analysis can also be done with the books written by other writers, and teachers can be guided in this respect.

\section{REFERENCES}

Note: References marked with an asterisk indicate studies included in the meta-analysis.

Ateşman, E. (1997). Türkçede okunabilirliğin ölçülmesi [Measuring readability in Turkish]. Dil Dergisi, 58, 7174.

Baş, B. \& İnan Yıldız, F. (2015). Review of texts in $2^{\text {nd }}$ class Turkish textbook in terms of readability. Mersin University Journal of the Faculty of Education, 11(1), 52-61.

Başaran, M. (2019). Türkçe ders kitabında yer alabilecek metinler ve metinlerle ilgili anlam kurma soruları [The texts that can be included in the Turkish textbook and questions about making sense of the texts].

Hayati Akyol and Ayfer Şahin (Eds). Türkçe ögrretimi: Öğretmen adaylarl ve ögretmenler için [Teaching Turkish: for pre-service teachers and teachers]. Pegem Akademi.

Bates, A.W. (2019). Teaching in a digital age ( $2^{\text {nd }}$ ed.). Tony Bates Associates Ltd. Retrieved March 3, 2021, from https://pressbooks.bccampus.ca/teachinginadigitalagev2/.

Chase, D. N. \& Cynthia, R. H. (1987). Reader response: An alternative way to teach students to think about text. International Literacy Association and Wiley, 30(6), 530-540.

Demir, Ş. (2019). A document analysis on Feridun Oral's picture story books. (Unpublished master's thesis). Hacettepe University.

Dilek, A. (2017). Review of values in Feridun Oral's illustrated story books., Journal of Values Education, 15(33), 61-86.

Flesh, R. (1948). A new readability yardstick. Journal of Applied Psychology, 32, 221-233.

Fraenkel, J. R., Wallen, N. E., \& Hyun, H. H. (2012). How to design and evaluate research in education. McGraw-Hill. 
Gay, L. R., Mills, G. E., \& Airasian, P. (2011). Educational research: Competencies for analysis and application. PrenticeHall.

Genette, G. (1997). Paratexts: Thresholds of interpretation. Cambridge University Press.

Güneş, F. (2000). Çocuk kitaplarının okunabilirlik ölçütleri açısından incelenmesi [Analysing Children's Books in Terms of Readability Criteria]. I. Ulusal Çocuk Kitapları Sempozyumu Sorunlar ve Çözüm Yolları [The First Symposium on National Children's Books: Problems and Ways to Solutions] (Yay. Haz. Doç. Dr. Sedat Sever). Ankara Üniversitesi Eğitim Bilimleri Fakültesi - TÖMER Dil Eğitim Merkezi.

Göğüş, B. (1978). Orta dereceli okullarımızda Türkçe ve yazın eğitimi [Turkish and literature education in our secondary schools]. Kadıŏlu.

Gönen, M. (2017). The place and educational values of Feridun Oral in our children's literature as a writing and drawing for children's literature. (Unpublished doctoral dissertation). Afyon Kocatepe University.

Higonnet, M. (1990). The playground of peritext. Children's Literature Association Quarterly, 15, 47-49.

Klare, G. (1988). Readability: The formative tears. (Ed. B. Zakaluk-S Jay Samuels), International Reading Assocation Inc.

Landis, J. R., \& Koch, G. G. (1977). The measurement of observer agreement for categorical data. Biometrics, $33,159-174$.

Lüle, E. (2007). Evaluation of seven juvenile books for their convenience to the principles of juvenile literature. Inönü University Journal of the Faculty of Education, 8(14), 17-30.

Mart, C. T. (2019). Reader- response theory and literature discussions: A springboard for exploring literacy texts. The New Educational Review. 56(2), 78-87.

Moss, J. F. (2005). Literature, literacy, and comprehension strategies in the elementary school. NCTE.

*Oral, F. (2020). Kirpi ile kestane [The hedgehog and the chestnut] (13 ${ }^{\text {th }}$ ed.). Yap1 Kredi Kültür Sanat.

*Oral, F. (2020). Kırmızı kanatlı baykuş [The owl with red wings] (11 $1^{\text {th }}$ ed.). Yap1 Kredi Kültür Sanat.

*Oral, F. (2020). Pirinç lapası ve küçük ejderha [Rice porridge and the little dragon] (7 ${ }^{\text {th }}$ ed.). Yapı Kredi Kültür Sanat.

*Oral, F. (2020). Baloncu dede ve üç küçük yaramaz [The old man who sells balloons and three little naughty children] ( $9^{\text {th }}$ ed.). Yapı Kredi Kültür Sanat.

*Oral, F. (2020). Kırmızı elma [The red apple] (15 ${ }^{\text {th }}$ ed.). Yap1 Kredi Kültür Sanat.

*Oral, F. (2020). Benekli faremi gördünüz Mü? [Have you seen my speckled mouse?] (11 ${ }^{\text {th }}$ ed.). Yap1 Kredi Kültür Sanat.

*Oral, F. (2019). Farklı ama aynı [Different but the same] (15 $5^{\text {th }}$ ed.). Yapı Kredi Kültür Sanat.

*Oral, F. (2019). Ay ne zaman gelecek? [When will the moon come?] (9 ${ }^{\text {th }}$ ed.). Yap1 Kredi Kültür Sanat.

*Oral, F. (2019). Bögürtlen cini ve sarl gaga [The blackberry genie and the yellow beak] (11 ${ }^{\text {th }}$ ed.). Yap1 Kredi Kültür Sanat.

*Oral, F. (2019). Guguklu saatin küçük kuşu [The little bird of the cuckoo clock] (4 ${ }^{\text {th }}$ ed.). Yap1 Kredi Kültür Sanat.

*Oral, F. (2019). Meyveleri kim yemiş? [Who ate the fruit?] ( $7^{\text {th }}$ ed.). Yap1 Kredi Kültür Sanat.

*Oral, F. (2015). Babaannem kime benziyor? [Who does my grandma look like?] 2 $2^{\text {nd }}$ ed.). Yapı Kredi Kültür Sanat.

*Oral, F. (2014). Yağmurlu bir gün [A rainy day] (1 $1^{\text {st }}$ ed.). Yapı Kredi Kültür Sanat.

Serafini, F. (2012). Interpreting visual images and design elements of contemporary picturebooks. Connecticut Reading Association Journal, 1, 3-8.

Sipe, L. R., \& Pantaleo, S. (2008). Postmodern picturebooks: Play, pradoy, and self-referentiality. Routledge.

Temizyürek, F. (2010). The investigation of the word and sentence length and the readability of the books which are selected in Turkey for the purpose of reading literacy. Journal of Türklük Bilimi Araştırmalart [TÜBAR], 27, 645-654.

Temur, T. (2003). Okunabilirlik kavramı [The concept of readability]. Türklük Bilimi Araştırmaları Türkçenin Öğretimi Özel Sayısı, 13, 169-180.

Toran, M. \& Dilek, A. (2017). Children and books: An evaluation according to Piaget's play theory. Education for Life, 31(1), 41-54.

Ural, S. (2006). Çocuk edebiyatı yapıtlarındaki yaşam gerçekliği [The Reality of Life in Works of Children Literature]. II. Ulusal Çocuk ve Gençlik Edebiyatı Sempozyumu. [The Second Symposium on National Children and Youth Literature]. Ankara Üniversitesi Eğitim Bilimleri Fakültesi.

Veziroğlu, M. \& Gönen, M. (2012). Review of the eligibility of picture books to the acquisition of the preschool education program of the ministry of national education. Education and Science, 37(163), 226-238.

Yalçın, A. \& Aytaş, G. (2003). Çocuk edebiyatı (Children literature). Akçağ.

Yıldırım, A. \& Şimşek, H. (2018). Sosyal bilimlerde nitel araştırma yöntemleri (Qualitative research methods in social sciences). Seçkin. 
Yıldız, C., Yazıcı, D. \& Durmuşoğlu, M. C. (2016). 2010-2015 yılları arasında yayımlanmış resimli çocuk kitaplarının resimleme özelliklerinin incelenmesi [An analysis of the illustration features of children's books published between 2010 and 2015]. Journal of Early Childhood Studies, 1(1), 43-55. 


\section{APPENDICES}

\section{Appendix 1: The themes, categories and codes contained in the books}

\begin{tabular}{|c|c|}
\hline $\begin{array}{l}\text { Theme: Values } \\
\text { Categories of books }\end{array}$ & Codes on subjects and main ideas \\
\hline \multirow{3}{*}{$\begin{array}{l}\text { The Old Man Who Sells Balloons and Three Little } \\
\text { Naughty Children }\end{array}$} & Code: Responsibility \\
\hline & Topic: Fairy chimneys \\
\hline & $\begin{array}{l}\text { Main idea: You should not do anything without permission from } \\
\text { elders }\end{array}$ \\
\hline \multirow[t]{3}{*}{ Have you Seen My Speckled Mouse? } & Code: Determination \\
\hline & Topic: Zeytin's looking for his mouse \\
\hline & $\begin{array}{l}\text { Main idea: You should keep looking for what you have lost until } \\
\text { you find it. }\end{array}$ \\
\hline \multirow[t]{3}{*}{ Who does My Grandma Look Like? } & Code: Respect \\
\hline & Topic: The characteristics of a grandmother \\
\hline & Main idea: Everybody has characteristics specific to him or her. \\
\hline \multirow[t]{3}{*}{ Different but the Same } & Code: Inclusiveness \\
\hline & Topic: A shepherd making a bicycle for a disabled boy to travel \\
\hline & Main idea: Obstacles can be overcome. \\
\hline \multirow[t]{3}{*}{ The Owl with Red Wings } & Code: Solidarity \\
\hline & Topic: A rabbit and his friends trying to pick up apples on a tree \\
\hline & Main idea: You can achieve your target through solidarity \\
\hline \multirow[t]{3}{*}{ Rice Porridge and the Little Dragon } & Code: Solidarity \\
\hline & Topic: The little dragon who wants to eat something on his birthday \\
\hline & $\begin{array}{l}\text { Main idea: Some of the things are enjoyable when you are with } \\
\text { your friends }\end{array}$ \\
\hline \multirow[t]{3}{*}{ A Rainy Day } & Code: Love for animals \\
\hline & Topic: Cem plays in his room on a rainy-day \\
\hline & Main idea: Your imagination can enable you to reach animals \\
\hline \multirow[t]{3}{*}{ The Little Bird of the Cuckoo Clock } & Code: Responsibility \\
\hline & Topic: The little bird of the cuckoo clock escapes from home \\
\hline & $\begin{array}{l}\text { Main idea: you should make sure that you close the door after going } \\
\text { out of your home }\end{array}$ \\
\hline \multirow[t]{3}{*}{ When will the Moon Come? } & Code: Helping each other \\
\hline & $\begin{array}{l}\text { Topic: The moon shows the rabbit the way with its light in the } \\
\text { forest }\end{array}$ \\
\hline & Main idea: Friendship means sharing and helping \\
\hline \multirow[t]{3}{*}{ The Red Apple } & Code: Solidarity \\
\hline & Topic: The rabbit and his friends try to pick up the apple on the tree \\
\hline & Main idea: You can achieve your target with solidarity \\
\hline \multirow[t]{3}{*}{ The Blackberry Genie and the Yellow Beak } & Code: Protecting nature and living creatures \\
\hline & Topic: The old tree which is burnt by stroke of lightning \\
\hline & Main idea: The importance of protecting nature and living creatures \\
\hline \multirow[t]{3}{*}{ Who ate the Fruit? } & Code: Protecting nature and living creatures \\
\hline & Topic: Slices of the lives of the animals in the forest \\
\hline & Main idea: We should think of animals when it is winter \\
\hline \multirow[t]{3}{*}{ The Hedgehog and the Chestnut } & Code: Responsibility \\
\hline & $\begin{array}{l}\text { Topic: A chestnut which sticks to the back of a hedgehog tries to be } \\
\text { unstuck }\end{array}$ \\
\hline & Main idea: We should tell our family whatever happens to us \\
\hline
\end{tabular}




\section{TÜRKÇE GENIŞLETILMIŞ ÖZET}

İlkokul çağındaki çocuklar için bir kitabın severek ve isteyerek okunmasını sağlayan üç temel husus vardır: kitabın yazılı metni, yazılı olmayan tüm diğer unsurlar ile konu ve ana fikri. Bu üç husustan ilki; çocuğun kitabı ilk gördüğü anda ilgisini çeken yazılı metin dışındaki tüm unsurlardır. $\mathrm{Bu}$ unsurlara peritextual özellikler denilmektedir. Bu yolla çocuk peritextual okuma gerçekleştirmektedir. Peritextual okuma kavramının Türkçede tam anlamıyla karşılığı bulunmamakla birlikte, peritextual okuma kavramını anlamak için öncelikle peritext kavramını açıklamakta fayda vardır. Resimli kitapların ön ve arka yüzü, kılıfı, ön kapaktan sonra ve arka kapaktan önce yer verilen boş sayfaları, başlık sayfası, iç kapak, yayıncı, resimleyen ve editör bilgilerinin yer aldığı sayfalar ve teşekkür gibi ithaf sayfalarının bulunduğu kısımlar peritext olarak bilinmektedir (Higonnet, 1990). Bu durumda kitabın dış kapağı, dış kılıfı ve fiziksel boyutu gibi biçimsel özellikleri de peritextual özellikleridir. Peritextual unsurlar okuyucunun diş dünyadan hikâye dünyasına geçişine aracilık etmektedir (Genette, 1997). Hikâyeyi çerçeveleyen bu unsurların okuyucuyu hikâyeye hazırlamak hedefiyle özenli ve dikkatli bir şekilde planlanması gerekmektedir (Sipe, 2010). Çünkü peritextual özellikler, okuyucu tarafından bir hikâyeyi okuyup okumamasına karar vermesini sağlamaktadır. Kitabın peritextual özelliklerinin keşfedilmesinden sonra çocuk metni okumaya başlar. Metni okumada okunaklılık ve okunabilirlik olmak üzere iki boyut vardır. Aslında çocuklar için metnin nasıl bir fontla hangi puntoda yazıldığı yani okunaklılığı peritextual özellikleri olarak düşünülebilir. Çünkü çocuk okumaya başlamadan önce bu özellikleri görsel olarak inceler, böylece metni okumaya karar verir. Farklı olarak okunabilirlik kavramı ise okuyan tarafından metinlerin güç ya da kolay anlaş1labilir olma durumudur (Ateşman, 1997).

Bu araştırmada Feridun Oral'ın çocuk kitaplarının ilkokul öğrencileri için peritextual özellikler ve metinlerin okunabilirlik açısından hangi düzeyde olduğunun, araştırma kapsamında seçilen kitapların işledikleri konu ve ana fikirlerin neler olduğunun belirlenmesi amaçlanmaktadır. Araştırma nitel yöntemlerden durum çalışması deseninin bütüncül çoklu durum desenine uygun olarak tasarlanmıştır. Veri kaynağı olarak Feridun Oral'ın özellikle tek başına yazıp çizdiği eserlerinden 13 hikâye kitabı kullanılmıştır. Çalışmada veri toplama yöntemi olarak doküman incelemesi kullanılmıştır. Araştırmada verilerin analizinde betimsel analiz ve tematik içerik analizi yöntemleri kullanılmıştır.

Feridun Oral'ın çocuk kitaplarının peritextual özellikleri ile metinlerinin okunabilirlik düzeyleri açısından incelenmesini amaçlayan bu araştırmada birinci alt problemde Feridun Oral çocuk kitaplarının ilkokul öğrencileri için, peritextual özellikleri nelerdir sorusuna yanıt aranmıştır. $\mathrm{Bu}$ bağlamda veri kaynakları içinde yer alan çocuk kitaplarından peritextual özellikler açısından en yüksek puanı alan kitap "Baloncu Dede ve Üç Küçük Yaramaz" iken en düşük puanı alan çocuk kitabı "Kirpi ile Kestane" olmuştur. Veri kaynakları olan kitapların tamamının peritextual özellikleri açısından birbirine yakın ve yüksek puanlar aldığ 1 görülmekle beraber tasarım özellikleri bakımından yazarın belirli uygulamaları tüm kitaplarına yansıttığı ortaya konmuştur. Moss'a (2005) göre resimli çocuk kitaplarında peritextual özelliklerin çocukların okuma öncesinde hikâye hakkında tahminde bulunmasına, ön bilgilerini harekete geçirmesine ve metin hakkında çıkarımlar yapmasına olanak sağladığı düşünüldüğünde yapılan çalışmada incelenen Feridun Oral kitaplarının ilkokul öğrencilerine fayda sağlayacağı söylenebilir. Gönen (2017) bu çalışmada elde edilen sonuçla paralel olarak Feridun Oral hikaye kitaplarıyla ilgili yapmış olduğu çalışmasında fiziksel, boyutsal ve biçimsel açıdan peritextual özelliklerin yüksek olduğu sonucuna ulaşmıştır. Başka bir çalışmada Demir (2019) ise yapılan bu çalışmayla paralel olarak, Feridun Oral hikaye kitaplarının resimlemelerinin, biçimsel açıdan \% 91, içeriksel açıdan \% 80 ve sanatsal açıdan \% 99 oranında niteliksel olduğu sonucuna ulaşmıştır. Peritextual okumanın özelliklerinden biri olan resimlemenin Feridun Oral kitaplarında etkili bir şekilde kullanıldığı görülmektedir.

Araştırmanın ikinci alt probleminde Feridun Oral çocuk kitaplarının ilkokul öğrencileri için, okunabilirlik açısından düzeyi nedir sorusuna yanıt aranmıştır. Araştırma kapsamında ele alınan tüm 
kitapların ortalaması incelendiğinde kitapların genel olarak kolay olduğu görülmektedir. Baş ve İnan Yıldız $(2015,52)$ ilkokul 2. Sınıf Türkçe ders kitabındaki metinleri okunabilirlik açısından incelemiş ve öyküleyici metinlerin okunabilirlik puanlarının bilgilendirici metinlerin okunabilirlik puanlarına göre daha yüksek olduğunu tespit etmişlerdir. Bu bulgu incelenen Ferdun Oral kitaplarının tümünün öyküleyici olması ve okunabilirlik açısından genel olarak kolay olması durumunu desteklemektedir. Bununla birlikte araştırmada incelenen kitaplardan en düşük okunabilirlik sayısına sahip ve dolayısıyla en zor kitabın "Baloncu Dede ve Üç Küçük Yaramaz", en yüksek okunabilirlik sayısına sahip ve dolayısıyla en kolay okunabilen kitabın ise "Kirpi ile Kestane" olduğu ortaya çıkmaktadır. Çocuk kitaplarında kullanılan kelimelerin ve cümlelerin kısa ve basit olması yapıtın okunabilirliğini artırmaktadır (Güneş, 2000, Temizyürek, 2010, 652). Araştırmada okunabilirlik kriteri yüksek olan "Baloncu Dede ve Üç Küçük Yaramaz" hikaye kitabının kelime uzunluğu 2.72 (ort.:2.59), cümle uzunluğu 15.65 (ort.: 8.56) ve okunabilirlik katsayıs1 48.41 (ort.: 72.41) olduğu görülmektedir. Araştırmada okunabilirlik kriteri yüksek olan "Kirpi ile Kestane" hikaye kitabının kelime uzunluğu 2.40 (ort.: 2.59), cümle uzunluğu 6.15 (ort.: 8.56) ve okunabilirlik katsayıs1 86.32 (ort.: 72.41) olduğu görülmektedir. Araştırmadan elde edilen sonuca göre, "Baloncu Dede ve Üç Küęük Yaramaz" hikâye kitabının kısa ve basit olmadı̆̆ı, "Kirpi ile Kestane" hikâye kitabının ise kısa ve basit olduğu görülmektedir. Bu durumda "Baloncu Dede ve Üç Küçük Yaramaz" kitabının peritextual özellikleri bakımından aldığı puan ile okunabilirlik özelliği bakımından aldığı puanın farklı olduğunu göstermektedir. Bu nedenle "Baloncu Dede ve Üç Küçük Yaramaz" kitabının zor olan okunabilirlik kriteri peritextual okuma yoluyla desteklenerek aşlabilecektir. $\mathrm{Bu}$ durum peritextual özelliklerin metnin okunmasına olan katkısını ortaya koymaktadır.

Araştırmanın üçüncü alt probleminde Feridun Oral çocuk kitaplarının ilkokul öğrencileri için, işledikleri konu ve ana fikirler nelerdir sorusuna yanıt aranmıştır. Veri kaynakları incelendiğinde "sorumluluk, azim, saygı, kapsayıcılık, dayanışma, yardımlaşma, hayvan sevgisi, doğayı ve canlıları koruma" kodlarıyla ortaya çıkan değerleri okuyucuya aşılamayı içermektedir. Bu kavramsal kodlar değerler teması altında birleşmektedir. Dilek (2017) Feridun Oral'ın resimli hikâye kitaplarındaki değerlerin incelenmesi başlıklı çalışmasında Feridun Oral hikâye kitaplarını MEB' in belirlemiş olduğu değerler üzerinden bir durum çalışması yapmıştır. Yapmış olduğu çalışmada, sevgi, sorumluluk, hoşgörü, dostluk, nazik olmak, yardımlaşma-dayanışma gibi farklı değerlerin ele alındığı sonucuna ulaşmıştır. Bu durum araştırmada elde edilen sonuçlarla paralellik göstermektedir. 